\title{
Calcium Activates a Chloride Conductance Likely Involved in Olfactory Receptor Neuron Repolarization in the Moth Spodoptera littoralis
}

\author{
Adeline Pézier, ${ }^{\star}$ Marta Grauso, ${ }^{\star}$ Adrien Acquistapace, Christelle Monsempes, Jean-Pierre Rospars, and Philippe Lucas \\ Unité Mixte de Recherche 1272 Physiologie de l'Insecte, Signalisation et Communication, Institut National de la Recherche Agronomique, F-78000 \\ Versailles, France
}

The response of insect olfactory receptor neurons (ORNs) to odorants involves the opening of $\mathrm{Ca}^{2+}$-permeable channels, generating an increase in intracellular $\mathrm{Ca}^{2+}$ concentration. Here, we studied the downstream effect of this $\mathrm{Ca}^{2+}$ rise in cultured ORNs of the moth Spodoptera littoralis. Intracellular dialysis of $\mathrm{Ca}^{2+}$ from the patch pipette in whole-cell patch-clamp configuration activated a conductance with a $K_{1 / 2}$ of $2.8 \mu \mathrm{m}$. Intracellular and extracellular anionic and cationic substitutions demonstrated that $\mathrm{Cl}^{-}$carries this current. The anion permeability sequence $\mathrm{I}^{-}>\mathrm{NO}_{3}^{-}>\mathrm{Br}^{-}>\mathrm{Cl}^{-}>\mathrm{CH}_{3} \mathrm{SO}_{3}^{-} \gg$ gluconate ${ }^{-}$of the $\mathrm{Ca}^{2+}$-activated $\mathrm{Cl}^{-}$channel suggests a weak electrical field pore of the channel. The $\mathrm{Ca}^{2+}$-activated current partly inactivated over time and did not depend on protein kinase $\mathrm{C}$ (PKC) and CaMKII activity or on calmodulin. Application of $\mathrm{Cl}^{-}$channel blockers, flufenamic acid, 5-nitro-2-(3-phenylpropylamino) benzoic acid, or niflumic acid reversibly blocked the $\mathrm{Ca}^{2+}$-activated current. In addition, lowering $\mathrm{Cl}^{-}$concentration in the sensillar lymph bathing the ORN outer dendrites caused a significant delay in pheromone response termination in vivo. The present work identifies a new $\mathrm{Cl}^{-}$conductance activated by $\mathrm{Ca}^{2+}$ in insect ORNs presumably required for ORN repolarization.

\section{Introduction}

Olfactory receptor neurons (ORNs) transduce the binding of odorant molecules to their cognate receptors into a graded membrane depolarization, the receptor potential (RP). This ultimately generates a train of action potentials (APs) encoding the relevant properties of the olfactory stimulus (Kaissling, 1986). The molecular mechanisms of the olfactory transduction pathway are now well established in vertebrates (Schild and Restrepo, 1998; Kleene, 2008) but remain partly unclear in insects despite decades of active research (Kaissling, 2004).

Although the origin of the RP in insect ORNs is unclear and the involvement of a canonical (metabotropic) and/or a noncanonical (ionotropic) pathway (Kain et al., 2008; Sato et al., 2008; Wicher et al., 2008) remains controversial, the initial steps in transduction do result in a rise in intracellular $\mathrm{Ca}^{2+}$ concentration (Stengl, 1994; Nakagawa-Inoue et al., 1998; Pézier et al., 2007; Sato et al., 2008; Wicher et al., 2008). Increased $\mathrm{Ca}^{2+}$ can potentially activate $\mathrm{Cl}^{-}$channels (Stengl et al., 1999; Dolzer,

Received Jan. 16, 2010; revised March 19, 2010; accepted March 25, 2010.

This work was supported by French-British Agence Nationale de la Recherche and Biotechnology and Biological Sciences Research Council SysBio 00601 "Pherosys," European FP7-ICT 2007 Small or medium-scale focused research project "Neurochem," Institut National de la Recherche Agronomique-Santé des Plantes et Environnement funding (to J.P.R. and P.L.), and a Ph.D. fellowship (to A.P.) from University Pierre et Marie Curie. We are grateful to Yuriy Bobkov and Kyrill Ukhanov for their critical reading of this manuscript.

*A.P. and M.G. contributed equally to this work and must both be considered as first authors.

Correspondence should be addressed to Philippe Lucas, Unité Mixte de Recherche 1272 Physiologie de I'Insecte, Signalisation et Communication, Institut National de la Recherche Agronomique, Route de Saint Cyr, F-78000 Versailles, France. E-mail: phillipe.plucas@versailles.inra.fr.

A. Pézier's present address: Institute of Neurobiology, University of Puerto Rico, San Juan PR-00901, Puerto Rico. DOI:10.1523/JNEUROSCI.0261-10.2010

Copyright $\odot 2010$ the authors $\quad 0270-6474 / 10 / 306323-11 \$ 15.00 / 0$
2002; Pézier and Lucas, 2006) as in vertebrate ORNs. The amplification cascade of vertebrate ORNs involves cAMP-activated $\mathrm{Ca}^{2+}$-permeable cationic channels, which allow an influx of $\mathrm{Ca}^{2+}$ into the cell (Restrepo et al., 1990; Leinders-Zufall et al., 1997; Dzeja et al., 1999). The $\mathrm{Ca}^{2+}$ rise opens $\mathrm{Cl}^{-}$channels (Kleene, 2002), resulting in an excitatory $\mathrm{Cl}^{-}$current (Kurahashi and Yau, 1993; Lowe and Gold, 1993; Zhainazarov and Ache, 1995) that can be the major component of the receptor current (Reisert et al., 2003; Boccaccio and Menini, 2007). The similarities in transduction between vertebrate and insect ORNs led us develop a model of insect transduction in which the $\mathrm{Cl}^{-}$current is also depolarizing ( $\mathrm{Gu}$ et al., 2009). However, an outward $\mathrm{Cl}^{-}$ flux has not been demonstrated in insect ORNs [assumption C in the study by Gu et al. (2009)].

The present work was undertaken to clarify the properties of insect ORNs and further determine the similarity to vertebrate ORNs in these respects. Two related questions were addressed: (1) Do insect ORNs express a $\mathrm{Ca}^{2+}$-dependent $\mathrm{Cl}^{-}$conductance? (2) If confirmed, is this conductance depolarizing and therefore involved in RP rise? To this end, we investigated currents activated by cytosolic $\mathrm{Ca}^{2+}$ in cultured ORNs of a moth. Whole-cell patch-clamp experiments were used to activate and record the $\mathrm{Ca}^{2+}$-dependent currents with known concentrations of $\mathrm{Ca}^{2+}$ by dialysis from the patch pipette.

(1) Results obtained gave clear evidence of the activation of a $\mathrm{Ca}^{2+}$-activated $\mathrm{Cl}^{-}$current whose biophysical and pharmacological properties were analyzed in detail. (2) In vivo, the increase in the duration of monosensillar responses to pheromone stimuli after reducing the sensillar $\mathrm{Cl}^{-}$concentration strongly suggests that $\mathrm{Cl}^{-}$channels are localized at the dendrite, and so involved in 
the RP generation, but most likely not in its rising (depolarizing) but in its falling (repolarizing) phase. This raises new questions on the ionic mechanisms involved in the RP generation and on the comparative physiology and evolution of ORNs.

\section{Materials and Methods}

Insects. Spodoptera littoralis moths (Lepidoptera, Noctuidae) were reared in our laboratory at $23^{\circ} \mathrm{C}$ and fed on an artificial diet. Pupae were sexed and males and females kept separately. Three-day-old male pupae were selected for primary cell cultures. One- to 3-day-old adult males were used for in vivo experiments.

Cell cultures. Primary cultures of $S$. littoralis male ORNs were prepared following the protocol previously reported (Lucas and Nagnan-Le Meillour, 1997) with slight modifications. Antennal flagella from 3-d-old male pupae were dissected. Cells were mechanically and enzymatically dissociated. Dispersed cells were plated onto uncoated Falcon Petri dishes in three parts of Leibovitz L15 medium, two parts of Grace medium conditioned on the embryonic cell line MRRL-CH1 (Eide et al., 1975 ), and $5 \%$ of fetal bovine serum (Invitrogen). Cultures were maintained in an incubator at $20^{\circ} \mathrm{C}$ before use. The culture medium was changed every $4-7 \mathrm{~d}$.

Whole-cell recordings. Patch-clamp experiments were performed on 10- to 21-d cultures at room temperature as previously described (Lucas and Shimahara, 2002). All recordings were done in voltage-clamp mode using the whole-cell configuration according to conventional patchclamp methods (Hamill et al., 1981). Electrodes were pulled from thickwall borosilicate capillaries (GC150-10, Harvard Apparatus) using a horizontal electrode puller (model P97, Sutter Instruments) to obtain a tip resistance of 3.5-5 $\mathrm{M} \Omega$ when filled with the standard intracellular solution. An Ag- $\mathrm{AgCl}$ reference electrode was connected to the bath through an agar bridge filled with recording electrode solution.

Currents were recorded with an Axopatch $200 \mathrm{~B}$ amplifier (Molecular Devices) and digitized at $20 \mathrm{kHz}$ using a Digidata 1322A (Molecular Devices). During whole-cell recordings, the membrane potential was clamped to $-60 \mathrm{mV}$. Data were acquired and analyzed with pClamp 9 and 10 (Molecular Devices). We measured both the peak amplitude of inward currents and the mean amplitude of steady-state currents calculated between 150 and $250 \mathrm{~s}$ after breaking into the whole-cell configuration.

Three types of voltage protocols were applied: ramp protocols of 500 $\mathrm{ms}$ duration from +80 to $-100 \mathrm{mV}$ and step protocols of 120 or $500 \mathrm{~ms}$ duration from -100 to $+80 \mathrm{mV}$ in $20 \mathrm{mV}$ increments. Current-voltage $(I-V)$ relationships were generated from voltage step protocols or ramp protocols. To subtract potential leak currents, currents recorded with voltage protocol generated within the first $5 \mathrm{~s}$ of whole-cell mode were subtracted from currents recorded during subsequent protocols.

Cell capacitance, determined from the capacitive current elicited by a $10 \mathrm{mV}$ depolarizing voltage step after establishment of whole-cell mode, ranged from 2 to $7 \mathrm{pF}(3.8 \pm 0.05 \mathrm{pF} ; n=542)$. Currents are expressed as density in picoamperes per picofarad.

Single sensillum recordings. To assess the role of $\mathrm{Cl}^{-}$currents in the response of insect ORNs to pheromone stimuli we performed in vivo recordings from single sensilla. The tip recording method was used to modify the ionic composition of the sensillar lymph as previously reported (Pézier et al., 2007). Briefly, recordings were performed on males from long sensilla trichodea that contain at least one neuron tuned to (Z,E)-9,11-tetradecadienyl acetate (Z9,E11-14:Ac), the main pheromone component of S. littoralis (Ljungberg et al., 1993). The recording electrode was slipped over the cut end of one hair. To minimize contributions of field potentials, the reference electrode was inserted close to the recording electrode into the adjacent segment. A humidified and charcoal-filtered airflow $(70 \mathrm{~L} / \mathrm{h})$ was continuously directed to the preparation. Pheromone stimulation consisted of blowing an air puff (200 $\mathrm{ms}, 10 \mathrm{~L} / \mathrm{h}$ ) through a Pasteur pipette containing $10 \mathrm{ng}$ of Z9,E11-14:Ac. The first pheromone response was recorded $1 \mathrm{~min}$ after connecting the recording electrode to a sensillum and then every $10 \mathrm{~min}$ for $30 \mathrm{~min}$ (four stimuli per sensilla). The biological signal was amplified $(\times 500)$ and low pass filtered online $(10 \mathrm{kHz})$ with an Axopatch 200B amplifier (Molecu-
Table 1. Compositions of pipette solutions for dose-response experiments

\begin{tabular}{llllll}
\hline Free $\mathrm{Ca}^{2+}(\mathrm{m})$ & $\begin{array}{l}\text { NMDG-Cl } \\
(\mathrm{mm})\end{array}$ & $\begin{array}{l}\mathrm{CaCl}_{2} \\
(\mathrm{~mm})\end{array}$ & $\begin{array}{l}\text { EGTA } \\
(\mathrm{mm})\end{array}$ & $\begin{array}{l}\text { HEDTA } \\
(\mathrm{mm})\end{array}$ & $\begin{array}{l}\text { NTA } \\
(\mathrm{mm})\end{array}$ \\
\hline $2 \times 10^{-8}$ & 153 & 1 & 11 & - & - \\
$1 \times 10^{-7}$ & 147.8 & 3.6 & 10 & - & - \\
$2.5 \times 10^{-7}$ & 143.4 & 5.8 & 10 & - & - \\
$5 \times 10^{-7}$ & 140.2 & 7.4 & 10 & - & - \\
$1 \times 10^{-6}$ & 152.4 & 1.3 & - & 10 & - \\
$1 \times 10^{-5}$ & 143 & 6 & - & 10 & - \\
$2.5 \times 10^{-5}$ & 139.2 & 7.9 & - & 10 & - \\
$1 \times 10^{-4}$ & 151.4 & 1.8 & - & - & 5 \\
$1 \times 10^{-3}$ & 153 & 1 & - & - & -
\end{tabular}

All solutions contained $10 \mathrm{~mm}$ HEPES. The pH was adjusted to 7.2 with NMDGOH, and osmotic pressure was 360 mosmol/L. Free $\mathrm{Ca}^{2+}$ concentrations were calculated with WebmaxC Standard (http://www.stanford.edu/ $\sim$ cpatton/webmaxc/webmaxcS.htm).

lar Devices) connected to a PC via a Digidata 1200A acquisition board (Molecular Devices). Sensillar potentials (SPs) were analyzed under pClamp 9.0 after low-pass filtering (Gaussian, $50 \mathrm{~Hz}$ ). APs were counted from high-pass-filtered traces $(50 \mathrm{~Hz})$ and pooled in $10 \mathrm{~s}$ bins. The spontaneous firing activity represents the frequency of APs calculated during the $10 \mathrm{~s}$ preceding each stimulus. The peak firing response and the poststimulus firing were calculated during the $200 \mathrm{~ms}$ stimulus and between 1 and $5 \mathrm{~s}$ after the stimulus, respectively.

Solutions and drugs. For whole-cell recordings, the standard intracellular pipette solution used as control consisted of the following (in $\mathrm{mM}$ ): $155 \mathrm{CsCl}, 1 \mathrm{CaCl}_{2}, 11$ EGTA, 10 HEPES, pH 7.2, adjusted to 330 mosmol/L with mannitol. The free $\mathrm{Ca}^{2+}$ concentration was $20 \mathrm{nM}$ as calculated with WebmaxC v.2.20. $\mathrm{Ca}^{2+}$-activated currents were activated with different $\mathrm{Ca}^{2+}$ concentrations in the pipette adjusted according to Table 1. Different calcium chelators were used according to their affinity for $\mathrm{Ca}^{2+}$ to obtain the different free $\mathrm{Ca}^{2+}$ concentration ranges. The different $\mathrm{Ca}^{2+}$ concentrations were tested on different sets of ORNs. In low- $\mathrm{Cl}^{-}$intracellular solution, methanesulfonate ${ }^{-}\left(\mathrm{CH}_{3} \mathrm{SO}_{3}^{-}\right)$or gluconate ${ }^{-}$replaced intracellular $\mathrm{Cl}^{-}$. In some experiments, choline ${ }^{+}$or $\mathrm{N}$-methyl-D-glucamine ${ }^{+}\left(\mathrm{NMDG}^{+}\right)$replaced $\mathrm{Cs}^{+}$.

Standard extracellular bath solution contained the following (in $\mathrm{mm}$ ): $155 \mathrm{NaCl}, 6 \mathrm{CaCl}_{2}, 4 \mathrm{KCl}, 5$ glucose, and 10 HEPES, pH 7.2, adjusted to $360 \mathrm{mosmol} / \mathrm{L}$ with mannitol. In low- $\mathrm{Cl}^{-}$bath solution, gluconate replaced external $\mathrm{Cl}^{-}$. The low- $\mathrm{Cl}^{-}$bath condition was used to generate inwardly rectified $\mathrm{Cl}^{-}$currents easier to recognize from potential linear leak currents. Tetraethylammonium (TEA)-Cl (20 mM) was added to the bath solution by equimolar replacement of $\mathrm{NaCl}$ to block voltage-gated $\mathrm{K}^{+}$channels. In anion relative permeability experiment, bath $\mathrm{NaCl}$ was substituted with equimolar quantities of $\mathrm{NaX}$, where $\mathrm{X}$ is the substituting anion.

To establish whether $\mathrm{Ca}^{2+}$-activated currents depend on cell volume, recordings were done with pipette solutions adjusted to an osmotic pressure of $360 \mathrm{mosmol} / \mathrm{L}$ and with bath solutions adjusted to $400 \mathrm{mosmol} / \mathrm{L}$ (hyperosmotic condition) or to $330 \mathrm{mosmol} / \mathrm{L}$ (hypoosmotic condition).

Threechloride channelblockers [flufenamic acid, 5-nitro-2-(3-phenylpropylamino) benzoic acid (NPPB), and niflumic acid], three protein kinase $\mathrm{C}$ (PKC) inhibitors (chelerythrine, staurosporine, and H7), and one $\mathrm{Ca}^{2+}$ /calmodulin (CaM)-dependent protein kinase II (CaMKII) inhibitor (KN93), were dissolved in dimethyl sulfoxide (DMSO). CaM and a CaM antagonist, $\mathrm{W}-7$, were dissolved in water. All stock aliquots were stored at $-20^{\circ} \mathrm{C}$ with the exception of $\mathrm{W}-7$, which was freshly prepared. For drug application, the final DMSO concentration was $\leq 0.1 \%$. This concentration of solvent had no effect on electrophysiological properties of ORNs.

For single sensillum recordings, the recording electrode contained either a standard $\mathrm{Cl}^{-}$solution containing the following (in mM): $172 \mathrm{KCl}, 22.5 \mathrm{glu}-$ cose, $10 \mathrm{HEPES}, 3 \mathrm{MgCl}_{2}, 1 \mathrm{CaCl}_{2}, 25 \mathrm{NaCl}$, pH 6.5, or a low- $\mathrm{Cl}^{-}$solution containing the following (in $\mathrm{mM}$ ): $172 \mathrm{~K}$-gluconate, 22.5 glucose, 10 HEPES, $3 \mathrm{MgCl}_{2}, 1 \mathrm{CaCl}_{2}, 25 \mathrm{Na}$-gluconate, $\mathrm{pH}$ 6.5. The reference electrode solution contained the following (in $\mathrm{mm}$ ): $6.4 \mathrm{KCl}, 340$ glucose, 10 
A

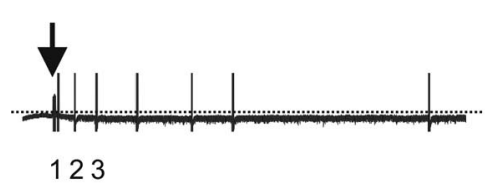

B $\quad 100 \mathrm{pA} \frac{}{100 \mathrm{~s}}$

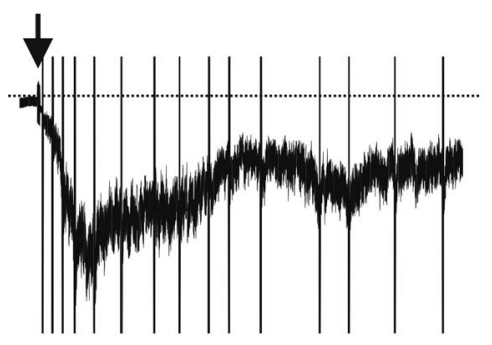

12
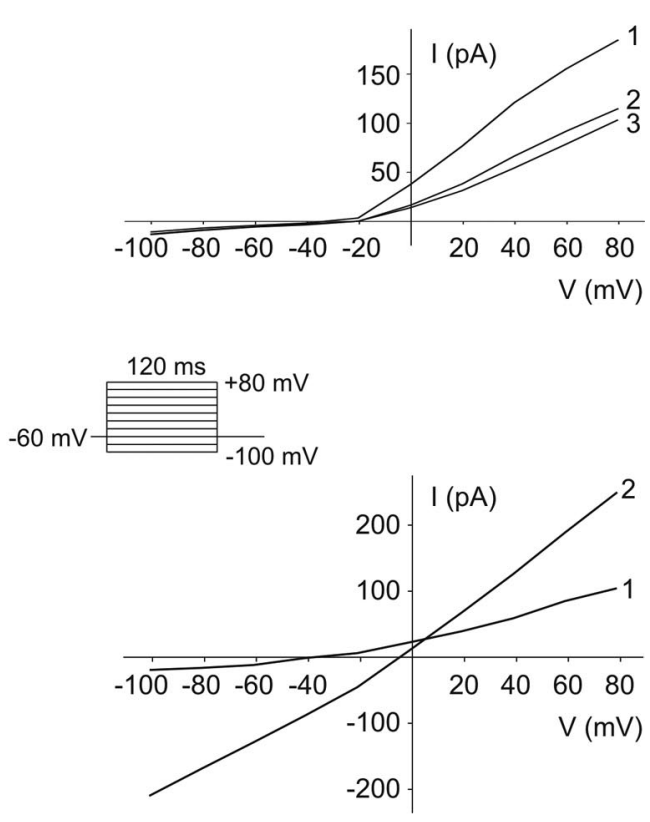

Figure 1. Calcium activates a current in Spodoptera littoralis ORNs in culture. $\boldsymbol{A}, \boldsymbol{B}$, Whole-cell currents recorded at a holding potential of $-60 \mathrm{mV}$ in the presence of $20 \mathrm{~nm}$ (control) $(\boldsymbol{A})$ or $100 \mu \mathrm{m}(\boldsymbol{B})$ free $\mathrm{Ca}^{2+}$ in the recording electrode $\left(E_{\mathrm{Cl}}=-2.6 \mathrm{mV}\right)$. Numbers under recordings indicate currents recorded during $120 \mathrm{~ms}$ step protocols from -100 to $+80 \mathrm{mV}$ used to establish $/-V$ relationships shown on the right. Dotted horizontal lines are zero current levels. Arrows indicate the transition from cell-attached to whole-cell configuration. Currents recorded during voltage protocols in $\boldsymbol{B}$ were truncated for clarity.

HEPES, $12 \mathrm{MgCl}_{2}, 1 \mathrm{CaCl}_{2}, 12 \mathrm{NaCl}, \mathrm{pH}$ 6.5. All solutions were adjusted to $450 \mathrm{mosmol} / \mathrm{L}$ with mannitol.

All drugs and chemicals were purchased from Sigma-Aldrich, except for the culture media (Invitrogen) and chelerythrine (Alomone).

Statistical analyses. Graphpad PRISM 5 software was used for plotting and curve fitting. All results are expressed as means \pm SEM. The nonparametric Mann-Whitney two-tailed test (for in vitro pharmacological and in vivo single sensillum experiments) and a one-way ANOVA followed by Dunnett's multiple-comparison test (for relative anion permeability and conductance experiments) were used to determine statistical significance of differences between groups. A $p$ value of $<0.05$ was accepted as a statistically significant difference.

\section{Results}

The following results describe and characterize a $\mathrm{Cl}^{-}$conductance activated by intracellular $\mathrm{Ca}^{2+}$ in cultured insect ORNs and show that $\mathrm{Cl}^{-}$is involved in the in vivo electrical response to pheromone stimulation.

\section{Intracellular $\mathrm{Ca}^{2+}$ activates a current in moth ORNs}

Neurons recorded at the resting intracellular $\mathrm{Ca}^{2+}$ concentration of $20 \mathrm{nM}$ (control condition) and maintained at a holding potential of $-60 \mathrm{mV}$ showed only a small amplitude inward current $(-6.2 \pm 1.4 \mathrm{pA} / \mathrm{pF} ; n=6)$ (Fig. $1 A)$. In this control condition, current to potential $(I-V)$ relationship showed the sole presence of voltage-dependent outwardly rectified currents with a fast rundown, flowing most probably through $\mathrm{Ca}^{2+}$-activated $\mathrm{K}^{+}$ channels (Lucas and Shimahara, 2002; Pézier et al., 2007). In contrast, most neurons recorded with $0.25 \mu \mathrm{M}$ or more internal $\mathrm{Ca}^{2+}(n=244$ of 311$)$ exhibited an inward current that slowly developed after breaking into the whole-cell configuration, reached a peak, and exhibited a marked decrease in amplitude to finally attain a steady state (Fig. $1 B$ ). The peak of the $\mathrm{Ca}^{2+}$ activated current was reached within $20-90 \mathrm{~s}$. The proportion in amplitude of the remaining steady-state current, averaged between 150 and $250 \mathrm{~s}$ after the acquisition of the whole-cell mode, was $28.7 \pm 2.7 \%(n=59)$ of the initial peak current elicited with 10 or $100 \mu \mathrm{M}$ internal $\mathrm{Ca}^{2+} . I-V$ relationship was almost linear with a reversal potential close to $0 \mathrm{mV}$. Because voltage-gated outward currents were not totally suppressed using Cs-based pipette solution, the following recordings were done with $20 \mathrm{~mm}$ TEA in the bath solution to block these currents except for experiments with $\mathrm{Cl}^{-}$channel blockers.

We then established the relationship between the amplitude of the $\mathrm{Ca}^{2+}$ activated current and the intracellular $\mathrm{Ca}^{2+}$ concentration from $20 \mathrm{~nm}$ to $1 \mathrm{~mm}$. Table 1 lists the compositions of the calcium-buffered solutions. Maximal current density was plotted against the concentration of free $\mathrm{Ca}^{2+}$ showing that the maximal current density was reached at $\sim 100 \mu \mathrm{M}$ free $\mathrm{Ca}^{2+}$ (Fig. 2). Fitting of the data to the Hill equation yielded a free $\mathrm{Ca}^{2+}$ concentration $K_{1 / 2}$ at half-maximum current density equal to $2.8 \mu \mathrm{M}$ and a Hill coefficient of 0.8 .

\section{The $\mathrm{Ca}^{2+}$-activated conductance is a $\mathrm{Cl}^{-}$current}

To determine the selectivity of channels activated by intracellular $\mathrm{Ca}^{2+}$, we compared the $I-V$ relationships and the reversal potentials of $\mathrm{Ca}^{2+}$-activated currents in different extracellular and intracellular ionic conditions. In symmetrical $\mathrm{Cl}^{-}$and cation concentrations, the $I-V$ relationship of the current activated with $100 \mu \mathrm{M} \mathrm{Ca}^{2+}$ was almost linear (Fig. $3 B)$ and the mean reversal potential was close to $0 \mathrm{mV}(-0.7 \pm$ $1.2 \mathrm{mV} ; n=10)$. When the nonpermeant cation choline ${ }^{+}$replaced $\mathrm{Na}^{+}$in the bath solution, the $I-V$ relationship of the $\mathrm{Ca}^{2+}$-activated current remained linear (Fig. $3 C$ ) and the mean reversal potential close to $0 \mathrm{mV}(3.8 \pm 3.1 \mathrm{mV} ; n=6)$. When intracellular $\mathrm{Cs}^{+}$was replaced with the nonpermeant cation choline ${ }^{+}$, no significant differences in the $I-V$ relationship (data not shown) and in the value of the reversal potential of the current $(-3.4 \pm 5.4 \mathrm{mV} ; n=8)$ were observed.

In contrast to cationic replacements, after the exchange of all

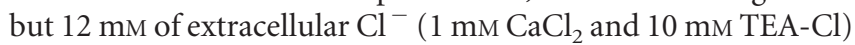
with gluconate ${ }^{-}\left(E_{\mathrm{Cl}}=65 \mathrm{mV}\right)$, the $\mathrm{Ca}^{2+}$-activated current became inwardly rectified (Fig. $3 D$ ) and the reversal potential averaged $67.1 \pm 4.9 \mathrm{mV}(n=13)$, indicating that the current is anionic. When ORNs were dialyzed with a low- $\mathrm{Cl}^{-}$intracellular solution containing either $0.2 \mathrm{mM} \mathrm{Cl}^{-}$and $100 \mu \mathrm{M} \mathrm{Ca}^{2+}(n=4)$ or $2 \mathrm{mM} \mathrm{Cl}^{-}$and $1 \mathrm{mM} \mathrm{Ca}^{2+}(n=4)$, through the replacement of internal $\mathrm{Cl}^{-}$with gluconate ${ }^{-}$, no inward and outward currents were activated during step protocols (Fig. $3 E$ ). Because the current block was not voltage dependent, gluconate ${ }^{-}$likely did not act as an open-channel blocker as in CFTR channels (Linsdell and Hanrahan, 1996). Replacement of $\mathrm{Cl}^{-}$on the cytosolic side not only by gluconate ${ }^{-}$but also by other halides or organic anions strongly reduced $\mathrm{Ca}^{2+}$-activated $\mathrm{Cl}^{-}$currents at both negative and positive potentials in patches excised from rat ORN dendritic knobs, indicating that cytosolic $\mathrm{Cl}^{-}$was necessary for the gating of this channel (Hallani et al., 1998). To evaluate whether $\mathrm{Cl}^{-}$was required for gating $\mathrm{Ca}^{2+}$-activated $\mathrm{Cl}^{-}$channels in $\mathrm{S}$. littoralis ORNs, intracellular $\mathrm{Cl}^{-}$was replaced by $\mathrm{Br}^{-}$. In this condition, 
A

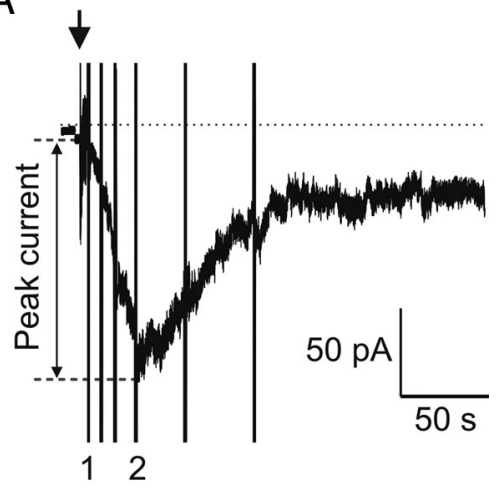

B

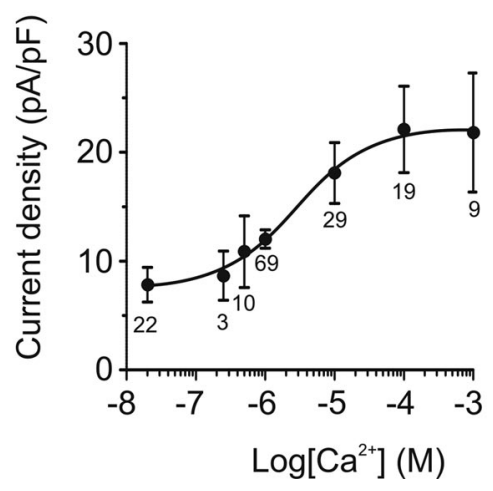

Figure 2. Chloride current density as a function of the free $\mathrm{Ca}^{2+}$ concentration in the patch electrode. $A$, Dose-response recordings (here an ORN dialyzed with $100 \mu \mathrm{m} \mathrm{Ca}{ }^{2+}$ ) were conducted in a low- $\mathrm{Cl}^{-}$external solution containing $20 \mathrm{~mm}$ TEA-Cl $\left(\mathrm{E}_{\mathrm{Cl}}=49 \mathrm{mV}\right)$. Current densities were measured as the peak current (maximal current - leak current) divided by the ORN capacitance. Dotted horizontal lines indicate zero current level. Arrow indicates the transition from cell-attached to whole-cell configuration. $\boldsymbol{B}$, Current densities were measured at the peak of the $\mathrm{Ca}^{2+}$-activated current. The curve fitted to the Hill equation has a $K_{1 / 2}$ of $2.8 \mu \mathrm{m}$ and a Hill coefficient of 0.8 . Numbers under each point indicate the number of replicates. Error bars represent SEM.

the dialysis of $100 \mu \mathrm{M} \mathrm{Ca}^{2+}$ activated a current whose reversal potential was only slightly shifted to positive potentials $(n=4)$ (Fig. $3 F$ ). Two different hypotheses can explain that the intracellular replacement of $\mathrm{Cl}^{-}$by $\mathrm{Br}^{-}$did not abolish the current: (1) either an intracellular permeant anion is required to gate this channel, or (2) gluconate ${ }^{-}$is an allosteric blocker or a blocker with a mechanism different from that of other known openchannel blockers (Cai et al., 2004; Linsdell, 2006; St Aubin et al., 2007). Based on our experiments, we cannot eliminate either hypothesis.

Altogether, ionic replacements demonstrated that the $\mathrm{Ca}^{2+}$ activated current is a $\mathrm{Cl}^{-}$current.

\section{Relative permeability and conductance of}

$\mathrm{Ca}^{2+}$-activated channels

The anion relative permeability and conductance of the $\mathrm{Ca}^{2+}$ activated channels were determined by substituting extracellular $\mathrm{Cl}^{-}$with other anions: the halides bromide and iodide, the polyatomic nonhalide nitrate, the organic methanesulphonate, and gluconate. Currents were activated by dialysis with $10 \mu \mathrm{M}$ free $\mathrm{Ca}^{2+}$ and recorded in $167 \mathrm{~mm}$ internal $\mathrm{Cl}^{-}$. Bath solutions contained $20 \mathrm{~mm}$ TEA-Cl and either $145 \mathrm{~mm} \mathrm{NaCl}\left(E_{\mathrm{Cl}}=0 \mathrm{mV}\right)$ or $145 \mathrm{~mm}$ of the substituting $\mathrm{NaX}\left(E_{\mathrm{Cl}}=51 \mathrm{mV}\right)$. Permeability ratios relative to $\mathrm{Cl}^{-}\left(P_{\mathrm{X}} / P_{\mathrm{Cl}}\right)$ were estimated by the shift in the reversal potential of the current under extracellular bianionic conditions (Yu et al., 2006) and were calculated using the Goldman-Hodgkin-Katz equation as follows: $P_{X} / P_{\mathrm{Cl}}=[\mathrm{Cl}]_{\mathrm{i}} /\left\{[\mathrm{X}]_{\mathrm{o}}\right.$ $\left.\exp \left(\Delta E_{\text {rev }} F / R T\right)\right\}-[\mathrm{Cl}]_{\mathrm{o}} /[\mathrm{X}]_{\mathrm{o}}$ with $\Delta E_{\text {rev }}=E_{\mathrm{X}}-E_{\mathrm{Cl}}$, where $E_{\mathrm{X}}$ is the reversal potential of the current in bianionic conditions, $F$ is the Faraday constant, $R$ is the gas constant and $T$ is the absolute temperature.

$E_{\text {rev }}$ values measured after subtraction of leak currents were

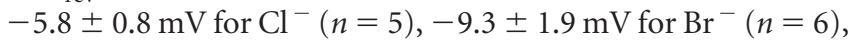

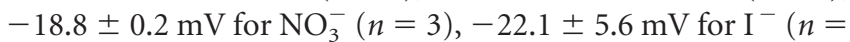
3), $5.2 \pm 1.8 \mathrm{mV}$ for $\mathrm{CH}_{3} \mathrm{SO}_{3}^{-}(n=8)$, and $52.1 \pm 8.9 \mathrm{mV}$ for gluconate $^{-}(n=9)$. Thus, the anion permeability sequence was $\mathrm{I}^{-}>\mathrm{NO}_{3}^{-}>\mathrm{Br}^{-}>\mathrm{Cl}^{-}>\mathrm{CH}_{3} \mathrm{SO}_{3}^{-} \gg$ gluconate ${ }^{-}$, and the relative permeability ratios were $\mathrm{I}^{-}: \mathrm{NO}_{3}^{-}: \mathrm{Br}^{-}: \mathrm{Cl}^{-}: \mathrm{CH}_{3} \mathrm{SO}_{3}^{-}: \mathrm{glu}-$ conate $^{-}=2.2: 1.8: 1.2: 1: 0.6: 0.02$ (Fig. $4 A$ ). This permeability sequence was inversely proportional to the hydration energies of tested anions (Frings et al., 2000), indicating that electrical field of the anion binding sites in the pore channel is weak and in consequence less hydrated anions permeate better through it. Gluconate did not permeate the calcium-activated $\mathrm{Cl}^{-}$channels, suggesting that the pore diameter is smaller than $5.8 \AA$, the size of the gluconate ion.

Because the rate of ion flux through the pore is mainly determined by the strength of interactions of ions with the binding site, high-affinity binding slows down ion flux and reduces channel conductance. Thus, we calculated the relative conductance of substituting anions versus $\mathrm{Cl}^{-}\left(G_{X} / G_{\mathrm{Cl}}\right)$. Because the mean $I-V$ relationships of the $\mathrm{Ca}^{2+}$-activated current for all tested extracellular anions were close to linear (Fig. 4B), we measured the slope of each $I-V$ relationship between -60 and $+60 \mathrm{mV}$ after subtraction of leak currents. The relative conductance ratios were $\mathrm{Cl}^{-}$: $\mathrm{I}^{-}: \mathrm{NO}_{3}^{-}: \mathrm{Br}^{-}: \mathrm{CH}_{3} \mathrm{SO}_{3}^{-}=1: 0.5: 0.5: 0.4: 0.2$ (Fig. 4C). All tested permeant anions produced a significantly lower conductance than $\mathrm{Cl}^{-}$. So, even if $\mathrm{I}^{-}$or $\mathrm{NO}_{3}^{-}$could leave more easily than $\mathrm{Cl}^{-}$ the hydrated state to better permeate the pore channel, they had higher affinity for ion binding sites than $\mathrm{Cl}^{-}$and produced lower conductances.

\section{$\mathrm{Ca}^{2+}$-activated current is not modulated by PKC, CaMKII, or calmodulin}

Some $\mathrm{Ca}^{2+}$-activated $\mathrm{Cl}^{-}$channels are known to be modulated by PKC or CaMKII (Boton et al., 1990; Kawasaki et al., 1994; Wang and Kotlikoff, 1997; Greenwood et al., 2001; Leblanc et al., 2005). We used a pharmacological approach to examine whether the $\mathrm{Ca}^{2+}$-activated $\mathrm{Cl}^{-}$current we identified in insect ORNs could also be modulated by PKC and CaMKII. $\mathrm{Cl}^{-}$currents activated with $10 \mu \mathrm{M}$ free $\mathrm{Ca}^{2+}$ were recorded after a minimum of 30 min incubation of ORNs in low- $\mathrm{Cl}^{-}$bath solution containing a CaMKII inhibitor (KN-93, $10 \mu \mathrm{M})$ or one of three PKC inhibitors (chelerythrine, $10 \mu \mathrm{M}, \mathrm{H} 7,10 \mu \mathrm{M}$, or staurosporine, $2 \mu \mathrm{M}$ ). None of these kinase modulators elicited any significant effect on $\mathrm{Ca}^{2+}$-activated current maximal density, time to reach the maximal density, or percentage of sustained current compared with DMSO control (Fig. 5).

Similarly, it has been suggested that CaM is involved in the gating of the $\mathrm{Ca}^{2+}$-activated $\mathrm{Cl}^{-}$channel in rat ORNs (Kaneko et al., 2006). We thus examined the effect of a direct application of intracellular CaM $(1 \mu \mathrm{M})$ through the pipette as well as the addition to the bath solution of a CaM antagonist, W-7, on various characteristics of the $\mathrm{Cl}^{-}$current activated with $10 \mu \mathrm{M}$ free $\mathrm{Ca}^{2+}$ - the maximal current density, the time to reach the peak, and the percentage of inactivation-compared with control recordings (Fig. 5). Both CaM (1 $\mu \mathrm{M})$ and W-7 (50 $\mu \mathrm{M})$ did not significantly modify any of these characteristics, except the time 
A
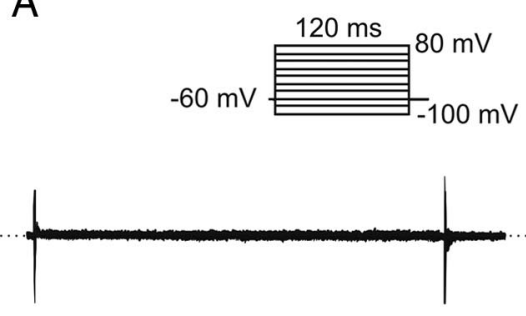

C
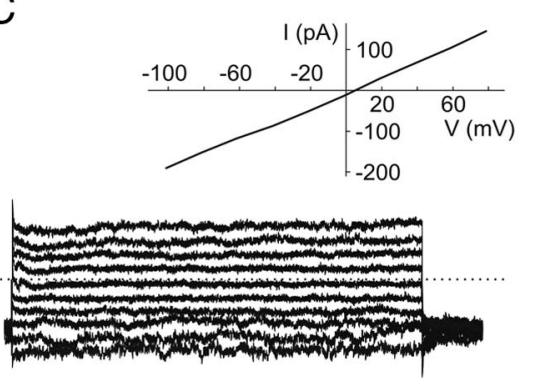

$\mathrm{E}$

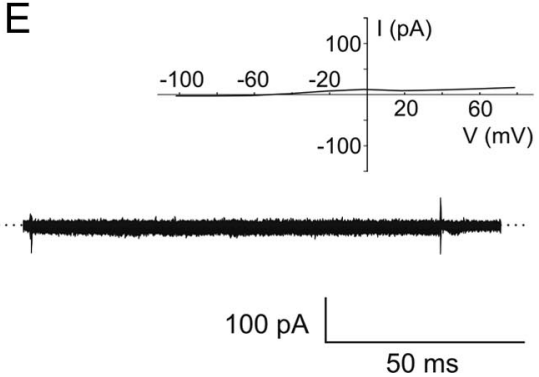

B
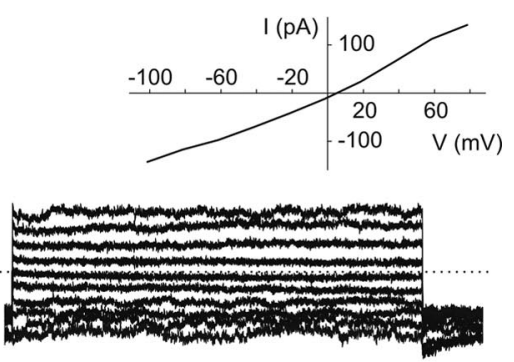

D
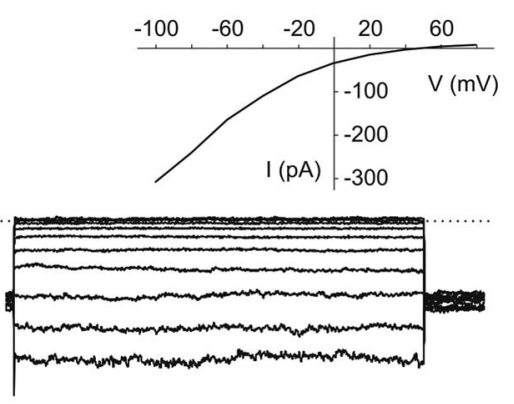

$\mathrm{F}$

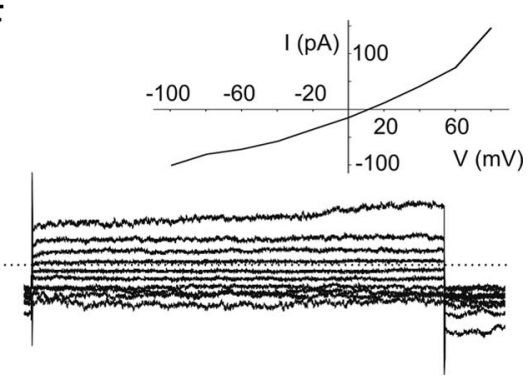

Figure 3. The $\mathrm{Ca}^{2+}$-activated current is selective for $\mathrm{Cl}^{-} . \boldsymbol{A}, \boldsymbol{B}$, Representative whole-cell currents recorded during step protocols and corresponding I-V relationships for ORNs dialyzed with $20 \mathrm{~nm}$ (control) $(\boldsymbol{A})$ or $100 \mu \mathrm{M}(\boldsymbol{B}-\boldsymbol{F})$ intracellular free $\mathrm{Ca}^{2+}$ in different intracellular and extracellular ionic conditions. Standard intracellular and bath solutions, with almost symmetric $\mathrm{Cl}^{-}$ concentrations $\left(E_{\mathrm{Cl}}=-2.3 \mathrm{mV}\right.$ in $\boldsymbol{A}$ and $-2.6 \mathrm{mV}$ in $\left.\boldsymbol{B}\right)$. $\boldsymbol{C}, \mathrm{Na}^{+}$-free bath solution and standard intracellular solution $\left(E_{\mathrm{Cl}}=\right.$ $-1.9 \mathrm{mV})$. D, Low-Cl ${ }^{-}$bath solution $\left(E_{\mathrm{Cl}}=65 \mathrm{mV}\right)$ and standard intracellular solution. $\boldsymbol{E}$, Standard bath solution and $0.2 \mathrm{~mm}$ intracellular $\mathrm{Cl}^{-}$(gluconate-based solution; $E_{\mathrm{Cl}}=-170 \mathrm{mV}$ ). $\boldsymbol{F}$, Standard bath solution and $0.2 \mathrm{~mm}$ internal $\mathrm{Cl}^{-}$(Br-based solution; $\left.E_{\mathrm{Cl}}=-170 \mathrm{mV}\right)$. Dotted horizontal lines are zero current levels.

to reach the peak current, which increased significantly $(p<$ $0.05)$ from $43.4 \pm 3.3 \mathrm{~s}(n=23)$ to $93.4 \pm 15.9 \mathrm{~s}(n=8)$ with the addition of CaM. This effect is opposite to what would be expected if $\mathrm{CaM}$ was required for gating $\mathrm{Cl}^{-}$channels. These results indicate that $\mathrm{CaM}$ is not required for current activation.

\section{Inhibitors of the $\mathrm{Ca}^{2+}$-activated current}

Despite the fact that no specific blockers of $\mathrm{Ca}^{2+}$-activated $\mathrm{Cl}^{-}$ currents are known, several compounds were found to inhibit these currents in vertebrates (Kleene, 2002). To begin to establish the pharmacological profile of the $\mathrm{Ca}^{2+}$-activated $\mathrm{Cl}^{-}$current, we tested three $\mathrm{Cl}^{-}$channel blockers, NPPB $(100 \mu \mathrm{M})$, flufenamic acid $(100 \mu \mathrm{M})$, and niflumic acid $(300 \mu \mathrm{M})$. To elicit the largest sustained currents possible, $1 \mathrm{~mm}$ internal $\mathrm{Ca}^{2+}$ was used. Drugs were applied on the steady-state current recorded from ORNs maintained at a holding potential of $-60 \mathrm{mV}$. Bath application of any of the three $\mathrm{Cl}^{-}$channel blockers reversibly inhibited the $\mathrm{Ca}^{2+}$-activated current and tail currents recorded at the completion of step protocols (Fig. 6). The sequence of inhibitory efficiency of the $\mathrm{Ca}^{2+}$-activated current was NPPB $>$ flufenamic acid $>$ niflumic acid (Table 2 ).

The reversibility of current inhibition was calculated by comparing the maximal amplitude of the inward current measured

after drug removal versus the amplitude of the inward current before inhibitor application. Interestingly, upon removal of the drug, we observed a transient peak current with a magnitude greater than the steady-state $\mathrm{Ca}^{2+}$-activated current observed before drug application (Fig. 6, stars; Table 2). After the rebound the current returned to the steady-state level observed before drug application.

\section{$\mathrm{Ca}^{2+}$-activated current does not depend on cell volume}

Some $\mathrm{Cl}^{-}$channels are regulated by both $\mathrm{Ca}^{2+}$ and cell volume (Fischmeister and Hartzell, 2005; Chien and Hartzell, 2007). Volume-regulated anion currents (VRACs) activate when the cell swells in extracellular hypo-osmotic condition resulting in an efflux of osmolytes such as $\mathrm{Cl}^{-}$and other organic anions (Nilius et al., 1997; Sardini et al., 2003). To determine whether the $\mathrm{Ca}^{2+}$-activated $\mathrm{Cl}^{-}$current we identified in ORNs has the characteristic of a VRAC, we analyzed the dependence of this current on cell volume.

Recordings were done in symmetrical $\mathrm{Cl}^{-}$concentrations $\left(E_{\mathrm{Cl}}=0 \mathrm{mV}\right)$. The pipette solution contained $100 \mu \mathrm{M}$ free $\mathrm{Ca}^{2+}$ with an osmotic pressure of 360 mosmol/L. The bath solution had an osmotic pressure adjusted with mannitol to $400 \mathrm{mosmol} / \mathrm{L}$ for the hyperosmotic extracellular condition or to $330 \mathrm{mosmol} / \mathrm{L}$ by omitting glucose for the hypo-osmotic extracellular condition. $\mathrm{Ca}^{2+}$-activated currents did not differ significantly between hyperosmotic and hypo-osmotic conditions in their $I-V$ relationship (Fig. 7) as well as in the maximal current densities $(21.5 \pm 8.7 \mathrm{pA} / \mathrm{pF}$ vs $20.5 \pm 7.8 \mathrm{pA} / \mathrm{pF} ; n=6)$, times to reach the maximal current density $(52.0 \pm 5.2 \mathrm{~s}$ vs $48.3 \pm 5.8 \mathrm{~s}$; $n=6)$, and percentages of sustained current $(21.7 \pm 5.7 \%$ vs $25.8 \pm 11.2 \% ; n=6$ ), indicating that $\mathrm{Ca}^{2+}$-activated $\mathrm{Cl}^{-}$currents do not depend on cell volume.

\section{In vivo responses to pheromone depend on the $\mathrm{Cl}^{-}$} concentration in the sensillar lymph

Next, we aimed to determine whether $\mathrm{Cl}^{-}$currents are involved in insect pheromone responses. The in vivo effects of application of $\mathrm{Cl}^{-}$channel blockers would not be easily interpreted because they are not specific to $\mathrm{Ca}^{2+}$-activated $\mathrm{Cl}^{-}$channels (Greenwood and Leblanc, 2007). Therefore, we modified the ionic concentrations in the sensillar lymph bathing outer dendrites using the tip recording method. The sensillum ringer commonly used in the tip recording technique contains $215 \mathrm{mM} \mathrm{Cl}^{-}$(Kaissling and Thorson, 1980). It was possible to reduce but not to increase the $\mathrm{Cl}^{-}$concentration in the recording electrode solution without modifying the osmotic pressure. Therefore, recordings were done with two different $\mathrm{Cl}^{-}$concentrations, $215 \mathrm{~mm}$ (standard $\mathrm{Cl}^{-}$) and $18 \mathrm{~mm}\left(\right.$ low $\mathrm{Cl}^{-}$), after the replacement of $\mathrm{Cl}^{-}$with gluconate $^{-}$. 


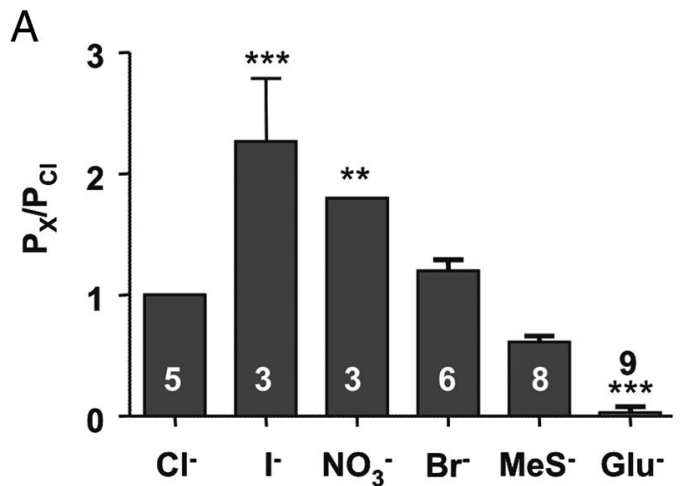

B
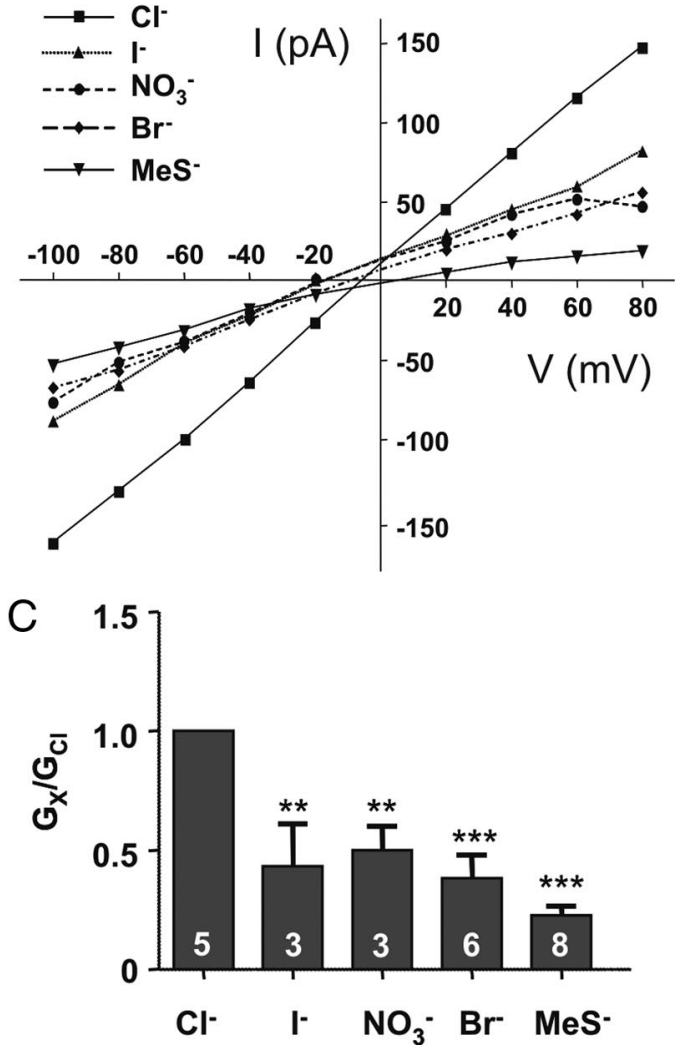

Figure 4. Anion relative permeability and relative slope conductance of $\mathrm{Ca}^{2+}$-activated current. Whole-cell currents were activated by dialysis with $10 \mu \mathrm{m}$ free $\mathrm{Ca}^{2+}$ and recorded in bath solutions containing either $145 \mathrm{~mm} \mathrm{NaCl}$ or $145 \mathrm{~mm}$ of the substituting $\mathrm{NaX}$. $A$, Anion relative permeabilities $P_{\mathrm{X}} / P_{\mathrm{Cl}}$ were calculated using the Goldman-Hodgkin-Katz equation from measured differences in $E_{\text {rev }}$ between symmetrical $\mathrm{Cl}^{-}$and bianionic conditions. $\boldsymbol{B}$, Mean $I-V$ relationships in bianionic conditions. C, Relative slope conductances $G_{X} / G_{C I}$ were obtained from the measurement of the slope of the $I-V$ relationships between -60 and $+60 \mathrm{mV}$. Numbers indicate replicates. Means \pm SEM. ${ }^{* *} p<0.01$; ${ }^{* * *} p<0.001$.

First, we verified that changing the $\mathrm{Cl}^{-}$concentration in the sensillar lymph does not change the properties of the sensillum at rest. There is a difference of potential between the sensillum lymph and the hemolymph, called the transepithelial potential (TEP), produced by the electrogenic activity of the accessory cells (Thurm and Wessel, 1979). At rest, the TEP maintains the membrane potential at the outer dendrite higher compared with the inner dendrite and soma and therefore controls the driving force at the transduction site (i.e., outer dendrite). Using recording and reference electrodes both filled with standard or low- $\mathrm{Cl}^{-}$solution, we did not measure any significant effect of the $\mathrm{Cl}^{-}$concen-

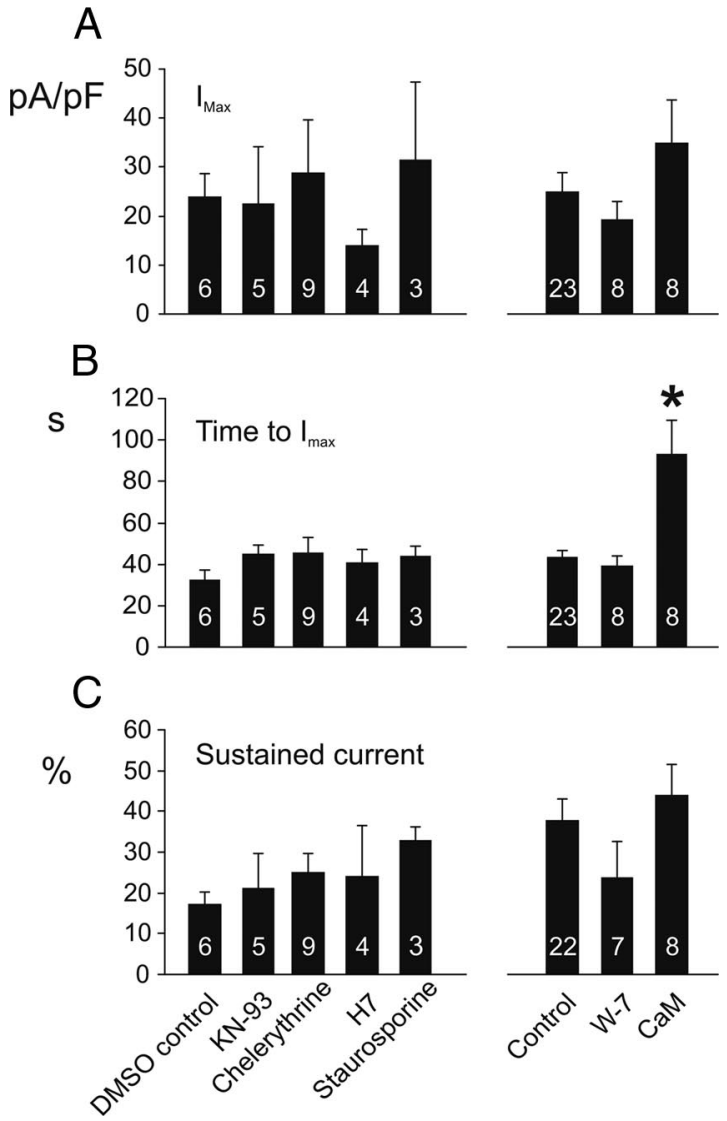

Figure 5. PKC, CaMKII, and CaM do not modulate the $\mathrm{Ca}^{2+}$-activated $\mathrm{Cl}^{-}$current. A CaMKII inhibitor, KN-93 $(10 \mu \mathrm{M})$, or one of three PKC inhibitors, chelerythrine $(10 \mu \mathrm{M}), \mathrm{H} 7(10 \mu \mathrm{M})$, or staurosporine $(2 \mu \mathrm{M})$, was added to the bath solution and their effects compared with a DMSO control. In a separate set of experiments, W-7 (50 $\mu$ M) was added to the bath solution or CaM (1 $\mu \mathrm{m})$ to the pipette solution and their effects were compared with control cells without drug. Currents were activated by dialysis of $10 \mu \mathrm{m}$ intracellular free $\mathrm{Ca}^{2+}$ and were recorded in low- $\mathrm{Cl}^{-}$bath solution containing $20 \mathrm{~mm}$ TEA. $A-C$, For each ORN were measured the maximal current density at $-60 \mathrm{mV}(\boldsymbol{A})$, the time to reach the maximal current intensity $(\boldsymbol{B})$, and the percentage of sustained current between 150 and 250 s of whole-cell mode ( $($ ). Legends below $\boldsymbol{C}$ are the same for $\boldsymbol{A}$ and $\boldsymbol{B}$. Numbers indicate replicates. Means \pm SEM. ${ }^{*} p<0.05$.

tration on the value of the TEP. After 10 min of contact between the sensillum and the electrode, the TEP averaged $29.6 \pm 4.0 \mathrm{mV}$ in standard $\mathrm{Cl}^{-}(n=7$ sensilla from 2 insects $)$ versus $27.5 \pm 3.5$ $\mathrm{mV}$ in low $\mathrm{Cl}^{-}$( $n=7$ sensilla from 3 insects) with the sensillar compartment being positive compared with the hemolymph. Therefore, the low $\mathrm{Cl}^{-}$concentration in the recording electrode does not modify the TEP. We also measured the spontaneous firing activity of ORNs. As for the TEP, at no time did the spontaneous activity vary significantly between recordings made in standard or in low- $\mathrm{Cl}^{-}$concentration over the $31 \mathrm{~min}$ of recordings: it decreased similarly in both $\mathrm{Cl}^{-}$conditions, from $2.9 \pm 0.5$ to $1.2 \pm 0.4 \mathrm{AP} / \mathrm{s}$ in low $\mathrm{Cl}^{-}$and from $3.4 \pm 0.6$ to $1.9 \pm 0.5 \mathrm{AP} / \mathrm{s}$ in standard $\mathrm{Cl}^{-}$.

Second, knowing that the properties of the sensillum at rest were maintained in our conditions, we analyzed the effect of $\mathrm{Cl}^{-}$ on ORN responses to odorants. In response to odorants, a slow negative deflection of the TEP called SP is generated. SP is known to reflect the receptor potential of ORNs (Vermeulen and Rospars, 2001). Recording SP allowed us to indirectly measure the effect of modifying the sensillar lymph $\mathrm{Cl}^{-}$concentration on the receptor potential. Over stimulations with $10 \mathrm{ng}$ of Z9,E11$14:$ Ac, the major pheromone compound of S. littoralis, a decrease 
A
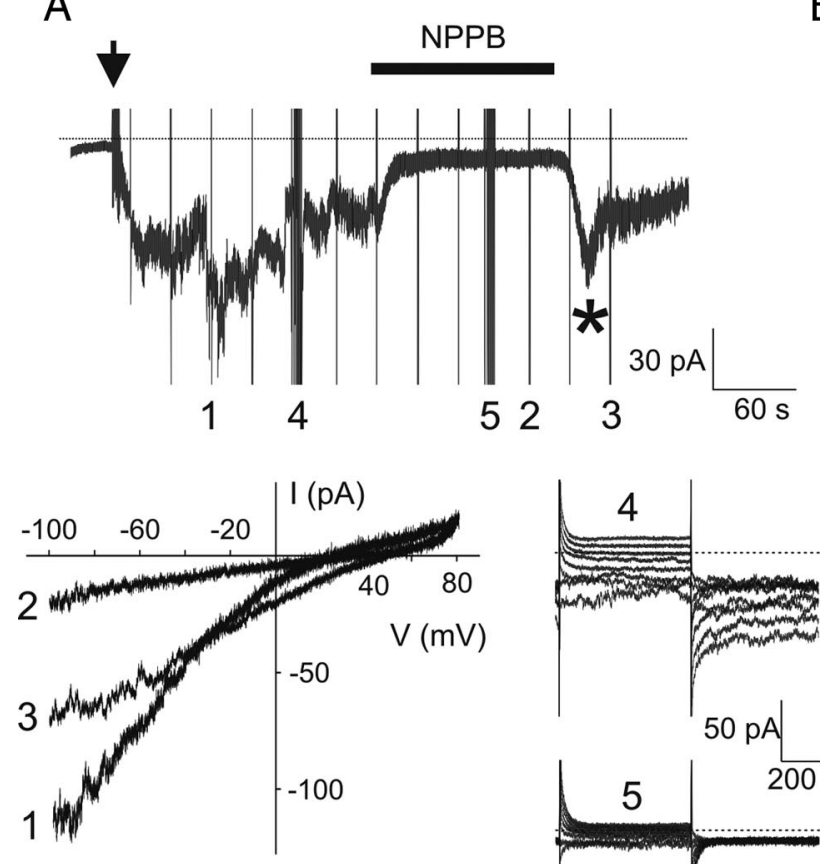

$-60 \mathrm{mV} \overbrace{-100 \mathrm{mV}}^{+80 \mathrm{mV}}$

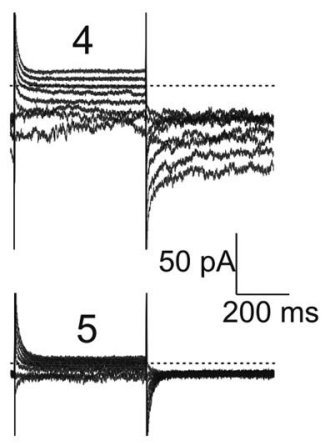

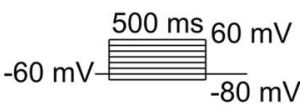

B

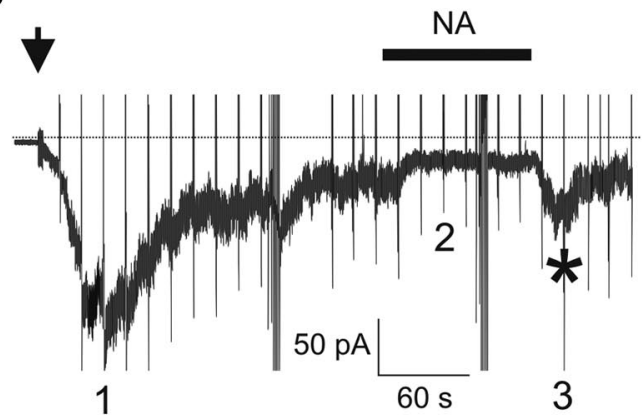

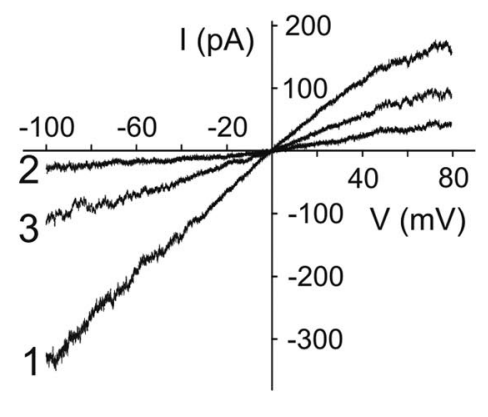

Figure 6. $\mathrm{Cl}^{-}$channel inhibitors reversibly block the $\mathrm{Ca}^{2+}$-activated current. $A, B$, Application of $100 \mu \mathrm{m} \mathrm{NPPB} \mathrm{(A)} \mathrm{or} 300 \mu \mathrm{m}$ niflumic acid (NA) (B) on the steady state of the whole-cell $\mathrm{Ca}{ }^{2+}$-activated current recorded at a holding potential of $-60 \mathrm{mV}$. Recordings were done in low- $\mathrm{Cl}^{-}$external solution in $\boldsymbol{A}$ and in symmetrical $\mathrm{Cl}^{-}$solutions in $\boldsymbol{B}$. Numbers (1), (2), and (3) are currents recorded during ramp protocols used to show $I-V$ relationships before, during, and after drug applications, respectively. Numbers (4) and (5) are currents recorded during step protocols before and during NPPB application, respectively. Note the tail currents blocked by the drug. Arrows indicate the transition from cell-attached to whole-cell configuration. Stars show the peak current observed upon drug removal. Currents recorded during voltage protocols were truncated for clarity.

Table 2. Summary of effects of three $\mathrm{Cl}^{-}$channel inhibitors tested on the $\mathrm{Ca}^{2+}$-activated current

\begin{tabular}{lllll}
\hline Inhibitors & Concentration & Numbers (\%) of ORNs inhibited & \% Inhibition & \% Recovery at the peak \\
\hline NPPB & $100 \mu \mathrm{M}$ & $15 / 16(94 \%)$ & $65.9 \pm 6.2(n=15)$ & $192.0 \pm 40.4(n=3)$ \\
Flufenamic acid & $100 \mu \mathrm{M}$ & $15 / 17(88 \%)$ & $57.2 \pm 7.4(n=15)$ & $181.5 \pm 48.6(n=8)$ \\
Niflumic acid & $300 \mu \mathrm{M}$ & $5 / 6(83 \%)$ & $50.2 \pm 6.7(n=5)$ & $137.5 \pm 19.1(n=3)$ \\
\hline
\end{tabular}

Percentage of inhibition is calculated as follows: $[1-(A / B)] \times 100$, where $A$ equals the amplitude of current during inhibitor application and $B$ equals the mean amplitude of current during 30 s just before inhibitor application. Percentage of recovery at the peak was used to analyze the reversible effect of inhibitors and is calculated as follows: $[C / B] \times 100$, where $C$ equals the amplitude of the peak current after washing out inhibitor. Means $\pm S E M$.

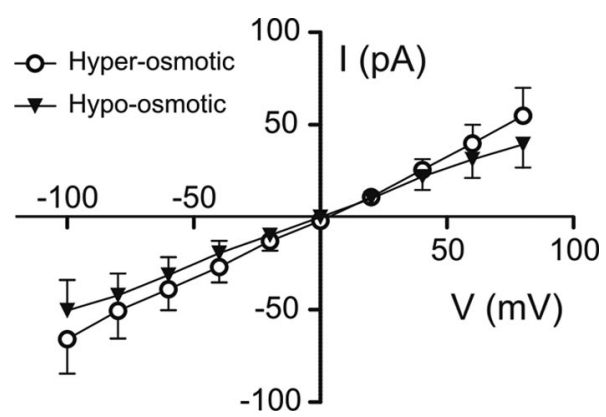

Figure 7. $\quad \mathrm{Ca}^{2+}$-activated $\mathrm{Cl}^{-}$currents do not depend on cell volume. I-V relationships of peak $\mathrm{Cl}^{-}$currents activated by dialysis of $100 \mu \mathrm{m}$ intracellular $\mathrm{Ca}^{2+}$ and recorded in symmetrical $\mathrm{Cl}^{-}$ concentrations $\left(E_{\mathrm{Cl}}=0 \mathrm{mV}\right)$. The osmotic pressure was adjusted to $360 \mathrm{mosmo} / \mathrm{L}$ in the pipette solution and to $400 \mathrm{mosmol} / \mathrm{L}$ (hyperosmotic condition; open circles) or to $330 \mathrm{mosmol} / \mathrm{L}$ (hypoosmotic condition; black triangles) in the bath solution. $n=6-9$. Means \pm SEM.

in SP amplitude was observed after the first stimulus both in standard and low- $\mathrm{Cl}^{-}$solution (Fig. $8 A, B$ ). To promote the best possible exchange between the recording electrode and the sensillar lymph we did not use polyvinyl pyrrolidone, a polymer that is commonly added to the recording electrode solution to keep intact the composition of the sensillar lymph during monosensillar recordings (Kaissling and Thorson, 1980). Therefore, the decrease in SP amplitude is most likely due to the dilution of sensillar proteins by the recording electrode solution, such as odorant-binding proteins or odorant-degrading enzymes, that are important for the ORN response (Pelosi, 1996). Despite higher SP amplitudes and peak firing responses in low- $\mathrm{Cl}^{-}$than in standard $\mathrm{Cl}^{-}$concentration after $11 \mathrm{~min}$, the difference was not significant at any time (Fig. $8 B-D$ ). Only the time to reach half of the maximal SP amplitude $\left(t_{1 / 2}\right)$ was significantly higher after 31 min (Fig. $8 C$ ). Therefore, lowering the $\mathrm{Cl}^{-}$concentration in the sensillar lymph had little effect on ORN depolarization.

In contrast, a significant effect of $\mathrm{Cl}^{-}$concentration on the falling phase of SP was observed. The percentage of repolarization was significantly reduced in low- $\mathrm{Cl}^{-}$condition when measured both at 0.8 or $10 \mathrm{~s}$ (Fig. $9 A, B$ ), suggesting that the sensillar $\mathrm{Cl}^{-}$concentration is essential for repolarization of the neuron. Similarly, the average poststimulus firing frequency measured between 1 and $5 \mathrm{~s}$ after stimulation was significantly higher in low 
than in standard $\mathrm{Cl}^{-}$condition (Fig. 9C). Therefore, the response termination clearly depended on the $\mathrm{Cl}^{-}$concentration in the recording electrode.

\section{Discussion}

In insect ORNs, odorants cause an influx of $\mathrm{Ca}^{2+}$ (Stengl, 1994; Nakagawa-Inoue et al., 1998; Pézier et al., 2007; Sato et al., 2008; Wicher et al., 2008). The consequences of elevated intracellular $\mathrm{Ca}^{2+}$ for ORN function are not fully understood. In this work, we provide evidence for a novel $\mathrm{Ca}^{2+}$-activated $\mathrm{Cl}^{-}$current in insect ORNs and propose that this current is involved in ORN repolarization corresponding to the RP falling phase.

\section{Functional properties of the}

\section{$\mathrm{Ca}^{2+}$-activated $\mathrm{Cl}^{-}$current}

The dialysis of $\mathrm{Ca}^{2+}$ in S. littoralis cultured ORNs activated a $\mathrm{Cl}^{-}$current, $I_{\mathrm{Cl}, \mathrm{Ca}}$. After reaching its maximal amplitude, $I_{\mathrm{Cl}, \mathrm{Ca}}$ decreased over time to a lower steady-state amplitude level. This current did not depend on PKC and CaMKII activity, nor on CaM, similar to what is seen for vertebrates, where no modulators of the olfactory $\mathrm{Ca}^{2+}$-dependent $\mathrm{Cl}^{-}$channels are known (Kleene, 2008). Rundown of $\mathrm{Cl}^{-}$current from excised patches of dendritic knobs from rat ORNs did not depend on $\mathrm{Ca}^{2+}$ concentration or CaM application (Reisert et al., 2003). Two different mechanisms can account for $I_{\mathrm{Cl}, \mathrm{Ca}}$ inactivation. First, because our experiments were done in the whole-cell configuration, current rundown could arise from elution of a soluble factor required for channel modulation. A second possibility is that the inactivation of $I_{\mathrm{Cl}, \mathrm{Ca}}$ is due to intrinsic properties of the channel.

Because of the important inactivation of $I_{\mathrm{Cl}, \mathrm{Ca}}$, the $\mathrm{Ca}^{2+}$ sensitivity of $I_{\mathrm{Cl}, \mathrm{Ca}}$ was not measured at the stationary phase but at the peak current. The half-maximal activation occurred near 3 $\mu \mathrm{M}$; it indicates a channel sensitivity to $\mathrm{Ca}^{2+}$ similar to $\mathrm{Ca}^{2+}$ dependent $\mathrm{Cl}^{-}$channels expressed in vertebrate ORNs (Kleene and Gesteland, 1991; Reisert et al., 2003; Pifferi et al., 2006). A Hill coefficient of less than one suggests a negative cooperativity of $\mathrm{Ca}^{2+}$ binding on channel activation. In vertebrate ORNs, gating of the $\mathrm{Cl}^{-}$channel is probably cooperative with a Hill coefficient ranging from 2.0 to 2.8 (Kleene, 2008). However, in $S$. littoralis ORNs $I_{\mathrm{Cl}, \mathrm{Ca}}$ inactivation probably led to underestimate peak currents. This resulted most likely in flattening the relation between $\mathrm{Ca}^{2+}$ concentration and $I_{\mathrm{Cl}, \mathrm{Ca}}$. More precise measurements of $K_{1 / 2}$ and Hill coefficient may require inside-out recordings to better control channel activation by $\mathrm{Ca}^{2+}$.

To get information about channel selectivity and anion permeation, we studied the relative permeability and conductance of $\mathrm{Ca}^{2+}$-activated $\mathrm{Cl}^{-}$channels. The anion permeability sequence $\mathrm{NO}_{3}^{-}>\mathrm{I}^{-}>\mathrm{Br}^{-}>\mathrm{Cl}^{-}>\mathrm{MeS}^{-}$is the same as for most other $\mathrm{Cl}^{-}$channels (Hartzell et al., 2005; Yang et al., 2008), including
B
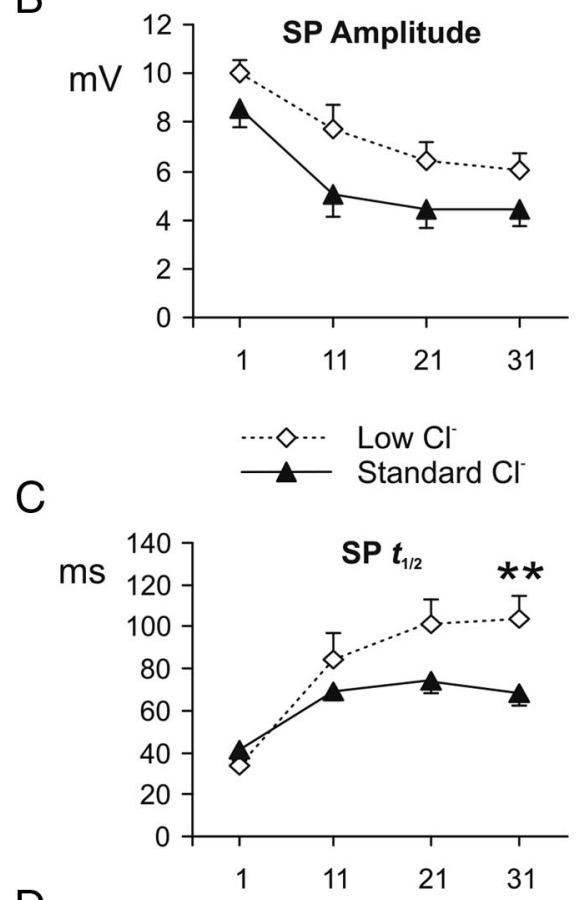

D

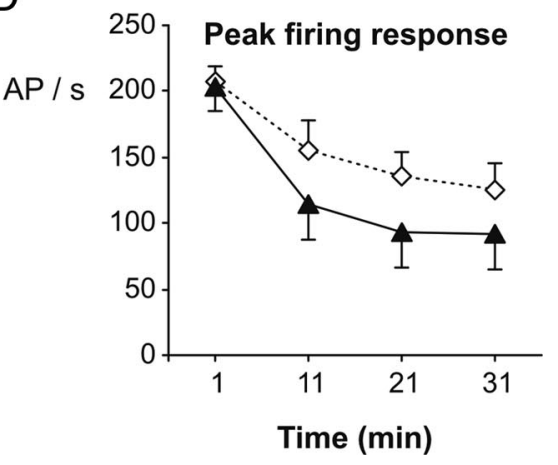

Figure 8. Lowering the $\mathrm{Cl}^{-}$concentration in the sensillar lymph has little effect on the amplitude and kinetic of the rising phase of the pheromone response. $A$, Low-pass-filtered sensillar potentials recorded in response to $10 \mathrm{ng}$ of Z9,E11:14:Ac (200 ms) with electrodes containing a standard $(215 \mathrm{~mm} ; n=19)$ or a low $(18 \mathrm{~mm} ; n=9) \mathrm{Cl}^{-}$concentration averaged under pClamp. $\boldsymbol{B}-\boldsymbol{D}$ Recordings were done after 1, 11, 21, and $31 \mathrm{~min}$ of contact between the sensillum and the recording electrode. Electrodes contained a standard $(215 \mathrm{~mm} ; n=19)$ or a low $(18 \mathrm{~mm} ; n=9) \mathrm{Cl}^{-}$concentration. Means \pm SEM. ${ }^{* *} p<0.01$.

$\mathrm{Ca}^{2+}$-activated $\mathrm{Cl}^{-}$channels expressed in rodent ORNs (Frings et al., 2000; Reisert et al., 2003; Pifferi et al., 2006). Relative conductance experiment suggests a pore channel with low affinity for $\mathrm{Cl}^{-}$, thus allowing a high flow rate of $\mathrm{Cl}^{-}$when the channel is open.

There are no specific inhibitors of olfactory $\mathrm{Cl}^{-}$channels (Kleene, 2002). The three compounds known to block vertebrate $\mathrm{Cl}^{-}$channels that we tested showed a blocking effect on $I_{\mathrm{Cl}, \mathrm{Ca}}$. The order of inhibitory effectiveness was NPPB $>$ flufenamic acid $>$ niflumic acid. The blockage of $I_{\mathrm{Cl}, \mathrm{Ca}}$ was reversible. In most cases, when the drug was rinsed, $I_{\mathrm{Cl}, \mathrm{Ca}}$ showed a transient rebound of the steady-state component to an amplitude higher than before drug application. This might indicate removal of inactivation during the time which the blocker was applied. This rebound did not exceed the peak current, indicating that the steady-state and peak components of $I_{\mathrm{Cl}, \mathrm{Ca}}$ are probably modulated by two different mechanisms.

In summary, channels responsible for $I_{\mathrm{Cl}, \mathrm{Ca}}$ in $S$. littoralis ORNs appear to work as most other olfactory $\mathrm{Cl}^{-}$channels, 
A

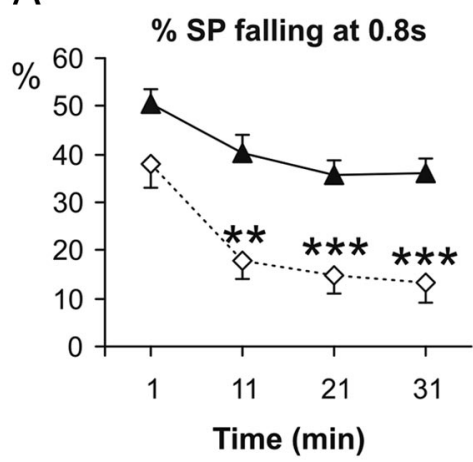

C

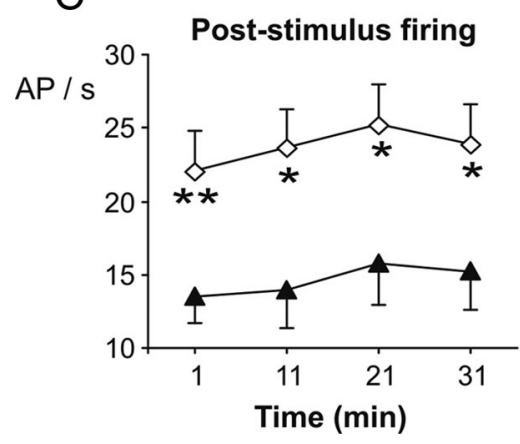

$\mathrm{B}$

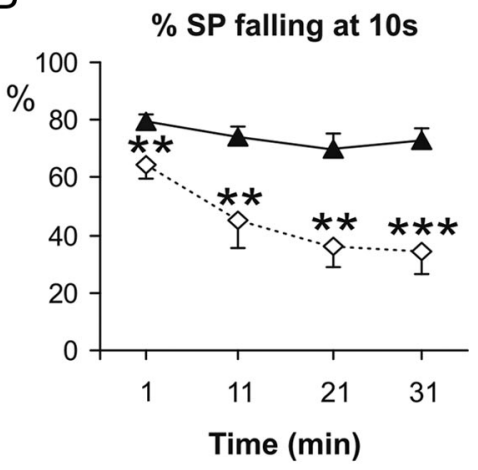

$\cdots \diamond \cdots$ Low $\mathrm{Cl}^{-1}$

$\simeq$ Standard $\mathrm{Cl}^{-}$

Figure 9. Response termination depends on the concentration of $\mathrm{Cl}^{-}$in the sensillar lymph. $\boldsymbol{A}-\boldsymbol{C}, \mathrm{SP}$ falling phase measured $0.8 \mathrm{~s}(\boldsymbol{A})$ and $10 \mathrm{~s}(\boldsymbol{B})$ after the beginning of the stimulus and $(\boldsymbol{C})$ poststimulus firing activity measured between 1 and $5 \mathrm{~s}$ after the beginning of the stimulus with $10 \mathrm{ng}$ of Z9,E11:14:Ac ( $200 \mathrm{~ms}$ ). Recording electrodes contained a standard ( $215 \mathrm{~mm} ; n=19$ ) or a low $(18 \mathrm{~mm} ; n=9) \mathrm{Cl}^{-}$concentration. Recordings were done after $1,11,21$, and 31 min of contact between the sensillum and the recording electrode. Means \pm SEM. ${ }^{*} p<0.05 ;{ }^{* *} p<0.01 ;{ }^{* * *} p<0.001$.

demonstrating similar $\mathrm{Ca}^{2+}$ sensitivity along with common properties such as lyotropic anion selectivity, open channel block from large polyatomic anion, and overlapping pharmacology. Different molecular candidates have been proposed to encode $\mathrm{Ca}^{2+}$-activated $\mathrm{Cl}^{-}$channels (Hartzell et al., 2005). In particular, bestrophin-2 (best-2) and anoctamin 2 (ANO2, also known as TMEM16B) are expressed in the cilia of mouse ORNs (Pifferi et al., 2006; Stephan et al., 2009) and were proposed to act as $\mathrm{Ca}^{2+}$-activated $\mathrm{Cl}^{-}$channels. If recent evidences refute that best-2 is the olfactory channel (Pifferi et al., 2009), ANO2 is still a strong candidate (Stephan et al., 2009). Several properties of the $\mathrm{Ca}^{2+}$-activated $\mathrm{Cl}^{-}$current expressed in S. littoralis ORNs, namely, $\mathrm{Ca}^{2+}$ sensitivity, current rundown, anion relative permeability, and niflumic acid inhibition, closely resemble those of recombinant $\mathrm{ANO} 2$, suggesting that this channel might be encoded in insects by a member of the TMEM16/anoctamin family.

\section{Involvement of the $\mathrm{Ca}^{2+}$-activated $\mathrm{Cl}^{-}$current in olfactory transduction}

After determining that $I_{\mathrm{Cl}, \mathrm{Ca}}$ is not regulated by the cell volume, we decided to assess whether this current is involved in ORN responses. We compared responses to pheromone stimuli recorded in low and standard extracellular $\mathrm{Cl}^{-}$concentration. The main effect of lowering the $\mathrm{Cl}^{-}$concentration was to slow the SP falling phase, which corresponds to a delayed ORN repolarization. Interestingly, similar reduced repolarizations were previously observed after lowering the $\mathrm{Ca}^{2+}$ concentration to $2 \times 10^{-8} \mathrm{M}$ (Pézier et al., 2007). The similarity of the modification of the SP when recordings were made in low $\mathrm{Cl}^{-}$or in low $\mathrm{Ca}^{2+}$, compared with standard extracellular $\mathrm{Cl}^{-}$and $\mathrm{Ca}^{2+}$ concentrations, is in good agreement with the involvement of a $\mathrm{Ca}^{2+}$-activated $\mathrm{Cl}^{-}$current in ORN responses. Moreover, it strongly suggests that $\mathrm{Ca}^{2+}$-dependent $\mathrm{Cl}^{-}$channels are localized in the outer dendritic membrane, the sole ORN membrane bathed by the sensillar lymph whose composition could be changed by the recording electrode.

The role played by $I_{\mathrm{Cl}, \mathrm{Ca}}$ in the ORN response, depolarizing or repolarizing, depends on the equilibrium potential $E_{\mathrm{Cl}}$ in the outer dendrite. $E_{\mathrm{Cl}}$ is still unknown because the intracellular and extracellular $\mathrm{Cl}^{-}$concentrations could not be measured. If the resting membrane potential is more negative than $E_{\mathrm{Cl}}, \mathrm{Cl}^{-}$flows out of the cell through open $\mathrm{Cl}^{-}$channels, which results in a depolarization of the plasma membrane. This is the case in mammalian ORNs, where the $\mathrm{Ca}^{2+}$-activated $\mathrm{Cl}^{-}$current amplifies the depolarizing current due to cyclic nucleotide-gated channels (Schild and Restrepo, 1998; Kleene, 2002). Conversely, if $E_{\mathrm{Cl}}$ is more negative than the resting potential, $I_{\mathrm{Cl}, \mathrm{Ca}}$ is repolarizing. Lowering the extracellular $\mathrm{Cl}^{-}$concentration, as we did in the sensillar lymph, is expected to increase the chemical gradient and therefore to increase the depolarization if $I_{\mathrm{Cl}, \mathrm{Ca}}$ is depolarizing, or to reduce the chemical gradient and therefore to reduce the repolarization if $I_{\mathrm{Cl}, \mathrm{Ca}}$ is repolarizing. In low- $\mathrm{Cl}^{-}$sensillar condition, we observed a slight but not significant increase in the depolarization, as indicated by larger SPs and stronger firing responses during the pheromone stimulation. In contrast, the low sensillar $\mathrm{Cl}^{-}$concentration induced a strong reduction of repolarization as indicated by delayed falling phase in SPs and in poststimulus firing activities, suggesting that the main effect of $I_{\mathrm{Cl}, \mathrm{Ca}}$ is to contribute to ORN repolarization.

Previous analysis of the ionic composition of the sensillar lymph indicated a low $\mathrm{Cl}^{-} / \mathrm{K}^{+}$ratio and a concentration of sulfur of $>100 \mathrm{~mm}$, suggesting a lack of anions that may possibly be compensated by sulfur-containing groups (Kaissling and Thorson, 1980). Moreover, strong pheromone stimulation further reduced the $\mathrm{Cl}^{-} / \mathrm{K}^{+}$ratio (Kaissling and Thorson, 1980). The latter observation is in good agreement with the involvement of a $\mathrm{Cl}^{-}$ current during ORN responses and supports the hypothesis of a $\mathrm{Cl}^{-}$entry within the ORN dendrite, leading to ORN repolarization. However the present evidence is not fully unequivocal [see discussion in the study by Gu et al. (2009)]. Previous $\mathrm{Cl}^{-}$measurements were described as rough estimates of relative concentrations of $\mathrm{Cl}^{-}$, so only new measurements of intracellular and extracellular $\mathrm{Cl}^{-}$concentrations can provide definitive evidence on the role of $I_{\mathrm{Cl}, \mathrm{Ca}}$ in moth pheromone transduction.

Another intriguing possibility is that $E_{\mathrm{Cl}}$ shifts during ORN response caused by $\mathrm{Cl}^{-}$depletion from the outer dendrite as proposed for cilia of vertebrate ORNs (Lindemann, 2001). In this case, $I_{\mathrm{Cl}, \mathrm{Ca}}$ would play a dual role, being depolarizing and then repolarizing during ORN responses. Regardless of any shift in $E_{\mathrm{Cl}}$, the proposed role in repolarization is counter to our assumption that this current was only depolarizing [our assumption $\mathrm{C}$ in 
the study by Gu et al. (2009)] and may necessitate a revision of our model for the transduction pathway.

A repolarizing role for the $\mathrm{Ca}^{2+}$-activated $\mathrm{Cl}^{-}$current in insects is the opposite of the depolarizing role played by similar channels in vertebrate ORNs. In the canonical vertebrate olfactory transduction cascades, this type of current amplifies depolarizing second messenger-gated cationic currents both in ORNs (Frings et al., 2000) and in vomeronasal sensory neurons (Yang and Delay, 2010). Although it is often noted how similar insect and vertebrate olfactory systems appear, likely as a result of convergent evolution, this difference may constitute a divergence across the two phyla.

\section{References}

Boccaccio A, Menini A (2007) Temporal development of cyclic nucleotidegated and $\mathrm{Ca}^{2+}$-activated $\mathrm{Cl}^{-}$currents in isolated mouse olfactory sensory neurons. J Neurophysiol 98:153-160.

Boton R, Singer D, Dascal N (1990) Inactivation of calcium-activated chloride conductance in Xenopus oocytes: roles of calcium and protein kinase C. Pflugers Arch 416:1-6.

Cai Z, Scott-Ward TS, Li H, Schmidt A, Sheppard DN (2004) Strategies to investigate the mechanism of action of CFTR modulators. J Cyst Fibros 3 [Suppl 2]:S141-S147.

Chien LT, Hartzell HC (2007) Drosophila bestrophin-1 chloride current is dually regulated by calcium and cell volume. J Gen Physiol 130:513-524.

Dolzer J (2002) Mechanisms of modulation and adaptation in pheromonesensitive trichoid sensilla of the hawkmoth Manduca sexta, p 119. Marburg, Germany: Philipps-Universität.

Dzeja C, Hagen V, Kaupp UB, Frings S (1999) $\mathrm{Ca}^{2+}$ permeation in cyclic nucleotide-gated channels. EMBO J 18:131-144.

Eide PE, Caldwell JM, Marks EP (1975) Establishment of two cell lines from embryonic tissue of the tobacco hornworm, Manduca sexta (L). In Vitro 11:395-399.

Fischmeister R, Hartzell HC (2005) Volume sensitivity of the bestrophin family of chloride channels. J Physiol 562:477-491.

Frings S, Reuter D, Kleene SJ (2000) Neuronal $\mathrm{Ca}^{2+}$-activated $\mathrm{Cl}^{-}$ channels-homing in on an elusive channel species. Prog Neurobiol 60:247-289.

Greenwood IA, Leblanc N (2007) Overlapping pharmacology of $\mathrm{Ca}^{2+}$ activated $\mathrm{Cl}^{-}$and $\mathrm{K}^{+}$channels. Trends Pharmacol Sci 28:1-5.

Greenwood IA, Ledoux J, Leblanc N (2001) Differential regulation of $\mathrm{Ca}^{2+}$ activated $\mathrm{Cl}^{-}$currents in rabbit arterial and portal vein smooth muscle cells by $\mathrm{Ca}^{2+}$-calmodulin-dependent kinase. J Physiol 534:395-408.

Gu Y, Lucas P, Rospars JP (2009) Computational model of the insect pheromone transduction cascade. PLoS Comput Biol 53:e1000321.

Hallani M, Lynch JW, Barry PH (1998) Characterization of calciumactivated chloride channels in patches excised from the dendritic knob of mammalian olfactory receptor neurons. J Membr Biol 161:163-171.

Hamill OP, Marty A, Neher E, Sakmann B, Sigworth FJ (1981) Improved patch-clamp techniques for high-resolution current recording from cells and cell-free membrane patches. Pflugers Arch 391:85-100.

Hartzell C, Putzier I, Arreola J (2005) Calcium-activated chloride channels. Annu Rev Physiol 67:719-758.

Kain P, Chakraborty TS, Sundaram S, Siddiqi O, Rodrigues V, Hasan G (2008) Reduced odor responses from antennal neurons of $\mathrm{G}_{\mathrm{q}} \alpha$, phospholipase $\mathrm{C} \beta$, and $r d g A$ mutants in Drosophila support a role for a phospholipid intermediate in insect olfactory transduction. J Neurosci 28:4745-4755.

Kaissling KE (1986) Chemo-electrical transduction in insect olfatory receptors. Annu Rev Neurosci 9:121-145.

Kaissling KE (2004) Physiology of pheromone reception in insects (an example of moths). ANIR 6:73-91.

Kaissling KE, Thorson J (1980) Insect olfactory sensilla: structural, chemical and electrical aspects of the functional organization. In: Receptors for neurotransmitters, hormones and pheromones in insects (Sattelle DB, Hall LM, Hildebrand JG, eds), pp 261-282. Amsterdam: Elsevier, North Holland Biomedical.

Kaneko H, Möhrlen F, Frings S (2006) Calmodulin contributes to gating control in olfactory calcium-activated chloride channels. J Gen Physiol 127:737-748

Kawasaki M, Uchida S, Monkawa T, Miyawaki A, Mikoshiba K, Marumo F,
Sasaki S (1994) Cloning and expression of a protein kinase C-regulated chloride channel abundantly expressed in rat brain neuronal cells. Neuron 12:597-604.

Kleene SJ (2002) The calcium-activated chloride conductance in olfactory receptor neurons. Curr Top Membr 53:119-134.

Kleene SJ (2008) The electrochemical basis of odor transduction in vertebrate olfactory cilia. Chem Senses 33:839-859.

Kleene SJ, Gesteland RC (1991) Calcium-activated chloride conductance in frog olfactory cilia. J Neurosci 11:3624-3629.

Kurahashi T, Yau KW (1993) Co-existence of cationic and chloride components in odorant-induced current of vertebrate olfactory receptor cells. Nature 363:71-74.

Leblanc N, Ledoux J, Saleh S, Sanguinetti A, Angermann J, O'Driscoll K, Britton F, Perrino BA, Greenwood IA (2005) Regulation of calciumactivated chloride channels in smooth muscle cells: a complex picture is emerging. Can J Physiol Pharmacol 83:541-556.

Leinders-Zufall T, Rand MN, Shepherd GM, Greer CA, Zufall F (1997) Calcium entry through cyclic nucleotide-gated channels in individual cilia of olfactory receptor cells: spatiotemporal dynamics. J Neurosci 17:41364148.

Lindemann B (2001) Predicted profiles of ion concentrations in olfactory cilia in the steady state. Biophys J 80:1712-1721.

Linsdell P (2006) Mechanism of chloride permeation in the cystic fibrosis transmembrane conductance regulator chloride channel. Exp Physiol 91:123-129.

Linsdell P, Hanrahan JW (1996) Flickery block of single CFTR chloride channels by intracellular anions and osmolytes. Am J Physiol 271:C628-C634.

Ljungberg H, Anderson P, Hansson BS (1993) Physiology and morphology of pheromone-specific sensilla on the antennae of male and female Spodoptera littoralis (Lepidoptera: Noctuidae). J Insect Physiol 39:253-260.

Lowe G, Gold GH (1993) Nonlinear amplification by calcium-dependent chloride channels in olfactory receptor cells. Nature 366:283-286.

Lucas P, Nagnan-Le Meillour P (1997) Primary culture of antennal cells of Mamestra brassicae: morphology of cell types and evidence for biosynthesis of pheromone-binding proteins in vitro. Cell Tissue Res 289:375-382.

Lucas P, Shimahara T (2002) Voltage- and calcium-activated currents in cultured olfactory receptor neurons of male Mamestra brassicae (Lepidoptera). Chem Senses 27:599-610.

Nakagawa-Inoue A, Kawahara S, Kirino Y, Sekiguchi T (1998) Odorantevoked increase in cytosolic free calcium in cultured antennal neurons of blowflies. Zool Sci 15:661-666.

Nilius B, Eggermont J, Voets T, Buyse G, Manolopoulos V, Droogmans G (1997) Properties of volume-regulated anion channels in mammalian cells. Prog Biophys Mol Biol 68:69-119.

Pelosi P (1996) Perireceptor events in olfaction. J Neurobiol 30:3-19.

Pézier A, Lucas P (2006) $\mathrm{Ca}^{2+}$ activates a $\mathrm{Cl}^{-}$current in moth olfactory receptor neurons. 17th ECRO, Granada, Spain. Chem Senses 31:E93.

Pézier A, Acquistapace A, Renou M, Rospars JP, Lucas P (2007) $\mathrm{Ca}^{2+}$ stabilizes the membrane potential of moth olfactory receptor neurons at rest and is essential for their fast repolarization. Chem Senses 32:305-317.

Pifferi S, Pascarella G, Boccaccio A, Mazzatenta A, Gustincich S, Menini A, Zucchelli S (2006) Bestrophin-2 is a candidate calcium-activated chloride channel involved in olfactory transduction. Proc Natl Acad Sci U S A 103:12929-12934.

Pifferi S, Dibattista M, Sagheddu C, Boccaccio A, Al Qteishat A, Ghirardi F, Tirindelli R, Menini A (2009) Calcium-activated chloride currents in olfactory sensory neurons from mice lacking bestrophin-2. J Physiol 587:4265-4279.

Reisert J, Bauer PJ, Yau KW, Frings S (2003) The Ca-activated Cl channel and its control in rat olfactory receptor neurons. J Gen Physiol 122:349-363.

Restrepo D, Miyamoto T, Bryant BP, Teeter JH (1990) Odor stimuli trigger influx of calcium into olfactory neurons of the channel catfish. Science 249:1166-1168.

Sardini A, Amey JS, Weylandt KH, Nobles M, Valverde MA, Higgins CF (2003) Cell volume regulation and swelling-activated chloride channels. Biochim Biophys Acta 1618:153-162.

Sato K, Pellegrino M, Nakagawa T, Nakagawa T, Vosshall LB, Touhara K (2008) Insect olfactory receptors are heteromeric ligand-gated ion channels. Nature 452:1002-1006. 
Schild D, Restrepo D (1998) Transduction mechanisms in vertebrate olfactory receptor cells. Physiol Rev 78:429-466.

St Aubin CN, Zhou JJ, Linsdell P (2007) Identification of a second blocker binding site at the cytoplasmic mouth of the cystic fibrosis transmembrane conductance regulator chloride channel pore. Mol Pharmacol 71:1360-1368.

Stengl M (1994) Inositol-triphosphate-dependent calcium currents precede cation currents in insect olfactory receptor neurons in vitro. J Comp Physiol A 174:187-194.

Stengl M, Ziegelberger G, Boekhoff I, Krieger J (1999) Perireceptor events and transduction mechanisms in insect olfaction. In: Insect olfaction (Hansson BS, ed), pp 49-66. Berlin: Springer.

Stephan AB, Shum EY, Hirsh S, Cygnar KD, Reisert J, Zhao H (2009) ANO2 is the cilial calcium-activated chloride channel that may mediate olfactory amplification. Proc Natl Acad Sci U S A 106:11776-11781.

Thurm U, Wessel G (1979) Metabolism-dependent transepithelial potential differences at epidermal receptors of Arthropods. I. Comparative data. J Comp Physiol 134:119-130.

Vermeulen A, Rospars JP (2001) Membrane potential and its electroderecorded counterpart in an electrical model of an olfactory sensillum. Eur Biophys J 29:587-596.
Wang YX, Kotlikoff MI (1997) Inactivation of calcium-activated chloride channels in smooth muscle by calcium/calmodulin-dependent protein kinase. Proc Natl Acad Sci U S A 94:14918-14923.

Wicher D, Schäfer R, Bauernfeind R, Stensmyr MC, Heller R, Heinemann SH, Hansson BS (2008) Drosophila odorant receptors are both ligand-gated and cyclic-nucleotide-activated cation channels. Nature 452:1007-1011.

Yang C, Delay RJ (2010) Calcium-activated chloride current amplifies the response to urine in mouse vomeronasal sensory neurons. J Gen Physiol 135:3-13.

Yang YD, Cho H, Koo JY, Tak MH, Cho Y, Shim WS, Park SP, Lee J, Lee B, Kim BM, Raouf R, Shin YK, Oh U (2008) TMEM16A confers receptoractivated calcium-dependent chloride conductance. Nature 455:12101215.

Yu K, Cui Y, Hartzell HC (2006) The bestrophin mutation A243V, linked to adult-onset vitelliform macular dystrophy, impairs its chloride channel function. Invest Ophthalmol Vis Sci 47:4956-4961.

Zhainazarov AB, Ache BW (1995) Odor-induced currents in Xenopus olfactory receptor cells measured with perforated-patch recording. J Neurophysiol 74:479-483. 